\title{
FUNGSI PENGGUNAAN DISFEMISME DALAM KOLOM KOMENTAR AKUN INSTAGRAM @OFFICIALKVIBES
}

\author{
Mawar Tri Handayani \\ Universitas Sebelas Maret \\ mawmarth@gmail.com
}

\begin{abstract}
Abstrak
Artikel ini bertujuan untuk mendeskripsikan fungsi penggunaan disfemisme yang terdapat dalam kolom komentar akun Instagram @officialkvibes. Data pada penelitian ini berupa kata, frasa, klausa, dan kalimat yang mengandung disfemisme dalam kolom komentar akun Instagram @officialkvibes. Metode penyediaan data yang digunakan dalam penelitian ini adalah metode simak dengan teknik simak bebas libat cakap dan teknik catat. Metode analisis data yang digunakan dalam penelitian ini adalah metode agih dengan teknik lesap serta metode padan referensial dan translasional dengan teknik pilah unsur penentu. Hasil penelitian menunjukkan bahwa fungsi penggunaan disfemisme dalam kolom komentar akun Instagram @officialkvibes adalah fungsi cemoohan (menghina atau merendahkan, menyindir), fungsi menunjukkan kejengkelan, fungsi menunjukkan ketidaksetujuan, dan fungsi menunjukkan emosi lain (kagum, senang).
\end{abstract}

Kata-kata kunci: disfemisme, fungsi disfemisme, Instagram @officialkvibes

\begin{abstract}
This article was carried out to describe the use of dysphemism in the comment sections of Instagram account @officialkvibes. The data of this research consisted of words, phrases, clauses, and sentences contained dysphemism in the comment section of one of Instagram account namely @officialkvibes. The data-supplying method in this research were observe method with uninvolved conversation observation technique and note-taking technique. The data analysis methods used were distributional methods with deletion technique and identity methods, namely referential and translational identity with determinant elements sorting technique. The conclusion of this research are the use of dysphemism found in the comment sections of Instagram account @officialkvibes are used to show insult (offend or down-grade, satirize), to show anger, to show dissaproval of, and to show other emotions (impressed, amused).

Keywords: dysphemism, the use of dysphemism, Instagram @officialkvibes
\end{abstract}

\section{PENDAHULUAN}

Hallyu atau Korean wave merupakan fenomena tersebarnya budaya pop Korea secara global di berbagai negara sejak 1990-an. Budaya pop Korea ini bukan hanya terbatas pada musik, tetapi juga meliputi drama serial, film, hingga fashion. Drama serial yang diekspor ke negara luar menjadi awal persebaran budaya pop Korea di dunia. Berawal dari drama serial, trend musik Korea juga mulai dikenal melalui soundtrack-soundtrack yang menjadi pemanis drama serial tersebut.

Dalam industri musik korea, setiap tahunnya digelar acara penghargaan musik bergengsi oleh beberapa stasiun TV swasta untuk mengapresiasi musisi di 
Negeri Gingseng tersebut. Megahnya perhelatan akbar ini mengakibatkan fandom atau komunitas penggemar baik dari Korea Selatan hingga seluruh belahan dunia, tidak terkecuali Indonesia, saling memperebutkan penghargaan tersebut untuk idolanya melalui sebuah vote.

Persebaran budaya pop Korea tersebut tidak lepas dari peranan teknologi hasil globalisasi yang semakin maju, salah satunya media sosial. Melalui Instagram, karya dan berbagai dukungan untuk idol Korea tersebar dengan semakin banyaknya akun-akun fanbase atau akun khusus penggemar dari idolidol tersebut.

Informasi terkait penghargaan musik tersebut pun disebarkan oleh akun penyedia informasi di media sosial yang dewasa ini jumlahnya semakin bertambah. Salah satunya adalah @officialkvibes. Akun portal news K-Pop di Indonesia tersebut tercatat memiliki pengikut sebanyak 614.000 akun. Menginjak akhir tahun 2019, sejalan dengan waktu pelaksanaan penghargaan musik tersebut, @officialkvibes tidak mau tertinggal dalam penyebaran informasi terkait melalui unggahannya di Instagram. Sejalan dengan hal ini, postingan tersebut sangat gencar dikomentari oleh para pengikut akun yang berisi berbagai fandom group Korea. Dari unggahan tersebut terdapat komentar positif dan negatif. Komentar negatif dalam konteks ini menjadi sebab terjadinya perang antar-fandom atau biasa disebut fanwar. Dalam fanwar tersebut banyak ditemukan komentar penghinaan atau penjatuhan antar-fandom, bahkan hingga ditujukan untuk penyelenggara acara tersebut. Komentar penghinaan dan penjatuhan tersebut dalam Semantik erat kaitannya dengan disfemisme.

Disfemisme menurut Allan dan Burridge (1991: 26) merupakan ungkapanungkapan yang berkonotasi menyakitkan atau mengganggu baik orang yang diajak bicara atau orang yang dibicarakan serta orang yang mendengarkan ungkapan tersebut. Disfemisme pada umumnya berupa penggunaan kata yang kasar dan lebih ofensif sehingga dikatakan kontras dengan eufemisme. Menurut Allan dan Burridge (2006: 31), disfemisme terkadang muncul karena adanya rasa takut dan tidak suka, tetapi juga karena adanya rasa kebencian dan bentuk penghinaan. Disfemisme digunakan untuk membicarakan tentang seseorang dan hal-hal yang membuat frustrasi serta mengganggu, untuk menunjukkan ketidaksetujuan dan ingin meremehkan, mempermalukan serta merendahkan seseorang. Dikatakan pula bahwa disfemisme adalah ciri khas kelompokkelompok politik dan kelompok-kelompok yang membicarakan lawan-lawan mereka; kaum feminis yang berbicara tentang pria; dan juga tentang kaum pria yang berbicara tentang wanita. Allan dan Burridge (1991: 28) memaparkan beberapa contoh ungkapan disfemisme seperti membandingkan atau menyamakan manusia dengan binatang misalnya bitch, pig, dan snake; menganggap ketidakmampuan mental atau fisik seperti idiot, moron, fuckwit, dan sebagainya. Beberapa penggunaan ekspresi hiperbola untuk menghina seseorang juga disebutkan oleh Allan dan Burridge (1991: 27) sebagai bentuk disfemisme 
seperti dalam "You great prick!" 'Manusia paling brengsek!' atau "He's the rottenest bastard I ever come across" 'Dia adalah bajingan terbusuk yang pernah aku temui'. Hiperbola juga digunakan dalam merendahkan seseorang seperti dalam "You slimy little toad!" 'Dasar katak kecil berlendir!', "The nasty little creep!" ‘Bajingan kecil yang jahat!' atau "Pea-brain!" ‘Otak kacang!’.

Disfemisme menjadi objek yang menarik untuk diteliti, khususnya penggunaannya dalam media sosial. Dewasa ini, penggunaan bahasa yang digunakan oleh warganet cenderung memprihatinkan. Seperti yang telah banyak diketahui, kontribusi dan feedback dalam media sosial dapat diberikan secara terbuka oleh siapapun. Demikian terbukanya, pengguna media sosial kini bebas mengungkapkan apapun yang dirasakannya. Kebebasan tersebut kemudian menyebabkan pengungkapan pikiran oleh pengguna media sosial dilakukan dengan penggunaan bahasa yang kasar dibanding bahasa yang halus. Dalam peperangan antar-fandom ini pun bisa dikatakan nilai kesantunan dalam diri para K-Popers, meskipun tidak semuanya, telah luntur, sehingga penggunaan ekspresi disfemisme dipilih dalam pengungkapan kekesalannya, bahkan ekspresi disfemisme digunakan dalam pelontaran komentar penghinaan atau penjatuhan untuk memancing kekesalan K-Popers lain.

Disfemisme biasanya dikaji penggunaannya dalam suatu media massa seperti penelitian yang telah dilakukan oleh Ramadhani (2017) dan Heryana (2019). Keduanya mengkaji disfemisme dalam media pers online. Meskipun demikian, penelitian tentang disfemisme dalam media sosial pun pernah dilakukan di Indonesia, seperti pada penelitian Ningsih (2016), Hermawan dkk (2018), dan Ulum (2018) yang mengkaji disfemisme oleh haters dalam kolom komentar akun Instagram, serta Aini (2018) yang mengkaji disfemisme dalam akun Twitter. Disfemisme dalam penelitian-penelitian tersebut secara garis besar dikaji mengenai bentuk dan fungsinya.

Berbeda dengan yang telah dilakukan dalam kajian-kajian sebelumnya, disfemisme dalam penelitian ini dikaji terkait fungsinya berdasarkan pendekatan semantik. Hal ini dikarenakan penelitian ini berfokus pada penggunaan disfemisme berdasarkan konteks sosial dan budaya seperti yang dikemukakan oleh Allan dan Burridge (2006: 32), "Connotations differ from context to context, from one community to another, and occasionally from one individual to another...Once again, the classification is wedded to context, place and time. The context makes all the difference...". Disfemisme bergantung pada suatu konteks, tempat, dan waktu. Allan dan Burridge (1991: 28) menyebutkan contoh tersebut sebagai berikut. Penyebutan kata Asian pada seseorang mungkin tidak akan bermakna negatif, tetapi jika kata Asian tersebut digunakan di Australia, mayoritas orang dari Asia akan merasa bahwa dideskripsikan sebagai Asians daripada sebagai Chinese, Indian, Kampuchean, atau Thai adalah sebuah disfemisme. Contoh lain juga disebutkan oleh Allan dan Burridge (2006: 31-32), yaitu penggunaan kata dog atau anjing. Penutur dapat menggunakan ungkapan anjing untuk merujuk pada 
entitas yang bukan berkaki empat. Tetapi jika referen ungkapan tersebut adalah manusia, ungkapan tersebut merupakan disfemisme. Hal itulah yang akan menjadi tolok ukur penentu sebuah ungkapan termasuk ke dalam disfemisme atau tidak. Selain itu, peneliti terdahulu terfokus pada akun pribadi publik figur Indonesia, sedangkan penelitian ini terfokus pada akun portal news K-Pop yang tidak hanya memberikan informasi terkait satu publik figur Korea Selatan yang memiliki latar budaya yang berbeda dengan masyarakat Indonesia.

Menurut Allan dan Burridge (1991: 27), “disfemisme digunakan untuk membicarakan tentang lawan, menunjukkan ketidaksetujuan seseorang, dan untuk merendahkan seseorang." Ekspresi disfemisme termasuk kutukan, namecalling, dan segala bentuk merendahkan ditujukan kepada orang lain untuk menghina atau melukai mereka. Penghinaan tersebut kemudian diperjelas lagi oleh Allan dan Burridge (2006: 79) yang mengatakan bahwa, "to insult someone verbally is to abuse them by assailing them with contemptuous, perhaps insolent, language that may include an element of bragging." "untuk menghina seseorang secara verbal adalah dengan melecehkan orang tersebut dengan bahasa yang menghina, mungkin kurang ajar, atau bahasa yang mungkin mengandung unsur menyombongkan diri.' Penghinaan ini biasanya diungkapkan secara langsung kepada orang yang dituju dengan penggunaan ungkapan "You asshole, you're a fucking tight-assed cunt. Get fucked". 'Bajingan. Kau benar-benar berengsek. Enyahlah.' Dalam bahasa Inggris, penggunaan ungkapan-ungkapan tersebut merupakan kata-kata hinaan yang memiliki konotasi sangat kasar.

Senada dengan hal ini, Zollner dalam Anggraeni (2016), disfemisme digunakan untuk merendahkan atau mengungkapkan penghinaan terhadap seseorang, untuk memperlihatkan rasa tidak suka kepada seseorang, memperlihatkan ketidaksetujuan terhadap seseorang, memperkuat atau mempertajam penghinaan sehingga orang yang mendengar semakin terluka, untuk mengungkapkan kemarahan atau kejengkelan terhadap seseorang, dan untuk mengumpat atau menunjukkan kekuasaan yang dimiliki.

Dalam kolom komentar akun @officialkvibes ditemukan banyak penggunaan disfemisme yang sangat tidak pantas digunakan dalam khalayak umum. Salah satu komentar yang ditemukan dalam kolom komentar @officialkvibes dapat dilihat pada data (1).

(1) ikkenurliandi gua mah heran aja sama fans yang bilang ulerlah yang bilang gak penting votenyalah masalahin penilaian dll MASALAHNYA LU VOTE GAK ANJENG? TEMEN" SEMUA FANDOM LU VOTE GAK? Jadi kalo obak lu pada gak menang PERTANYAIN SOAL DUKUNGAN FANDOM LU SENDIRI. Gak usah bacot ini itu padahal sendirinya gak dukung obaknya. Emosi anjeng baca komenan yang bilang begitu, cuma ngedukung obaknya pas menang doang. Usahanya kaga ada. TOLONG TENGGELAMKAN FANS MACAM BEGITU. Dukung aja dulu opak lu anjeng. (04/OKV/25/OKT/19)

Pada data (1) terdapat ekspresi disfemisme berupa kata anjeng. Anjeng merupakan bentuk variasi lain dari kata anjing. Menurut KBBI daring, anjing 
berarti binatang menyusui yang biasa dipelihara untuk menjaga rumah, berburu, dan sebagainya. "A speaker could use dog to refer to an entity which is not a canine quadruped. If the referent were humans, then the expression is dysphemistic." 'Penutur dapat menggunakan ungkapan anjing untuk merujuk pada entitas yang bukan anjing berkaki empat. Tetapi jika referen ungkapan tersebut adalah manusia, ungkapan tersebut merupakan disfemisme' (Allan dan Burridge, 2006: 31-32). Berdasarkan hal tersebut, ungkapan anjeng pada data (1) termasuk dalam disfemisme karena ungkapan tersebut ditujukan pada seseorang. Selain itu, anjing dalam sebuah peribahasa anjing ditepuk menjungkit ekor memiliki konotasi kasar, yaitu orang hina.

Penggunaan ekspresi disfemisme ini berfungsi untuk mengungkapkan kejengkelan. Hal ini ditandai dengan unsur gramatikal lain yang mendampingi ungkapan anjeng. Pada kalimat awal, ditemukan ungkapan MASALAHNYA LU VOTE GAK, lalu pada kalimat selanjutnya ditemukan kata emosi yang mendampingi kata anjeng. Penggunaan huruf kapital dapat mempertegas suatu kemarahan. Nuansa kekesalan juga dapat dilihat pada kata emosi yang kemudian diikuti kata anjeng. Hal tersebut menunjukkan rasa jengkel penulis kepada seseorang dalam komentarnya. Pengungkapan suatu kejengkelan, apapun alasannya, sangatlah tidak pantas jika diutarakan dalam ungkapan yang berkonotasi kasar. Apalagi jika hal tersebut dilakukan dalam sebuah media sosial, hal tersebut tentu saja tidak hanya akan terbaca oleh penutur komentar tersebut.

Sehubungan dengan hal ini, penelitian ini terfokus pada satu fenomena yaitu fanwar atau perang antar-fandom K-Pop yang terjadi pada bulan Oktober, November, dan Desember 2019, sejalan dengan akan diadakannya, saat pelaksanaan, dan setelah pelaksanaan penghargaan musik tersebut. Jika ditinjau dari penelitian-penelitian yang telah dilakukan oleh peneliti terdahulu, belum ditemukan penelitian kebahasaan yang terfokus pada fenomena fanwar, khususnya dalam media sosial Instagram.

Pemilihan fenomena fanwar didasarkan pada semakin maraknya peperangan antar-fandom dari berbagai idola Korea Selatan tersebut. Dalam fenomena fanwar, penggunaan ungkapan-ungkapan berkonotasi kasar sangat banyak dijumpai, khususnya dalam media sosial. Hal ini cukup memprihatinkan karena media sosial tidak hanya sebagai konsumsi pribadi. Komentar tersebut dikonsumsi oleh seluruh masyarakat pengguna media sosial, mengingat bahwa akun @officialkvibes merupakan akun yang sangat terbuka bagi semua pengguna Instagram.

Berdasarkan pemaparan fenomena kebahasaan dan data di atas, disfemisme dalam akun @officialkvibes menarik untuk dikaji. Penelitian ini membahas mengenai fungsi penggunaan disfemisme dalam kolom komentar akun Instagram @officialkvibes dengan pendekatan Semantik. Tujuan dari 
penelitian ini adalah untuk mendeskripsikan fungsi penggunaan disfemisme pada kolom komentar akun @officialkvibes.

\section{METODE PENELITIAN}

Jenis penelitian ini adalah kualitatif dengan bentuk deskriptif, yaitu penelitian yang bertujuan untuk memahami fenomena tentang apa yang dialami oleh subjek penelitian misalnya perilaku, persepsi, motivasi, tindakan, dan sebagainya, dengan cara deskripsi dalam bentuk kata-kata pada suatu konteks khusus yang alamiah dan dengan memanfaatkan berbagai metode alamiah (Moleong, 2005: 9). Konteks alamiah yang dimaksud dalam penelitian ini adalah komentar-komentar yang terdapat dalam akun Instagram @officialkvibes. Komentar-komentar tersebut dikatakan alamiah dan dideskripsikan secara alamiah karena tidak ada bentuk manipulasi penggunaan bahasa yang diamati. Selain itu, penelitian ini tergolong dalam penelitian kualitatif dengan bentuk deskriptif karena tujuan penelitian ini adalah untuk memaparkan secara detail mengenai penggunaan bahasa dalam kolom komentar akun Instagram @officialkvibes.

Data yang digunakan dalam penelitian ini adalah satuan-satuan lingual berwujud kata, frasa, klausa, dan kalimat yang mengandung disfemisme dalam kolom komentar akun Instagram @officialkvibes. Sumber data penelitian ini adalah akun Instagram @officialkvibes. Data tersebut dikumpulkan dari komentar-komentar warganet yang memberikan feedback pada unggahan akun @officialkvibes selama kurun waktu tiga bulan, yaitu bulan Oktober, November, dan Desember 2019, sejalan dengan adanya fanwar yang terjadi akibat acara penghargaan musik Korea Selatan.

Metode penyediaan data yang digunakan dalam penelitian ini adalah metode simak dengan teknik simak bebas libat cakap (Sudaryanto, 2015: 204) dan teknik catat (Sudaryanto, 2015: 210). Artinya, peneliti tidak terlibat langsung dalam sumber data penelitian yang memunculkan data tertentu yang termasuk sebagai disfemisme. Data yang telah dikumpulkan kemudian dianalisis menggunakan metode agih dengan teknik lesap serta metode padan referensial dan translasional dengan teknik pilah unsur penentu.

\section{ANALISIS DAN PEMBAHASAN}

Berdasarkan teori fungsi disfemisme oleh Allan dan Burridge (1991), ditemukan 4 fungsi penggunaan disfemisme dalam kolom komentar akun Instagram @officialkvibes. Berikut tabel fungsi disfemisme yang ditemukan dalam kolom komentar akun Instagram @officialkvibes. 
Tabel 1

Fungsi Disfemisme dalam Kolom Komentar Akun Instagram @officialkvibes

\begin{tabular}{lcc}
\hline \multicolumn{1}{c}{ Fungsi Disfemisme } & Jumlah & Persentase \\
\hline Cemoohan (menghina atau merendahkan, menyindir) & 66 & $46.8 \%$ \\
\hline Mengungkapkan kejengkelan & 66 & $46.8 \%$ \\
\hline Menunjukkan ketidaksetujuan & 5 & $3.6 \%$ \\
\hline Menunjukkan emosi lain (kagum, senang) & 4 & $2.8 \%$ \\
\hline Jumlah & $\mathbf{1 4 1}$ & $\mathbf{1 0 0} \%$ \\
\hline
\end{tabular}

Berdasarkan tabel 1, dapat dilihat bahwa dalam kolom komentar akun Instagram @officialkvibes terdapat empat fungsi penggunaan disfemisme yang ditemukan. Fungsi-fungsi tersebut terdiri dari fungsi cemoohan sebanyak 66 data dengan persentase sebesar $46.8 \%$, untuk mengungkapkan kejengkelan sebanyak 66 data dengan persentase sebesar $46.8 \%$, untuk menunjukkan ketidaksetujuan sebanyak 5 data dengan persentase sebesar 3.6\%, dan untuk menunjukkan emosi lain sebanyak 4 data dengan persentase sebesar 2.8\%. Berdasarkan rincian tersebut, dapat disimpulkan bahwa disfemisme paling sering digunakan untuk mencemooh dan mengungkapkan kejengkelan dalam kolom komentar akun Instagram @officialkvibes.

Berikut pembahasan fungsi penggunaan disfemisme yang ditemukan dalam kolom komentar akun Instagram @officialkvibes.

\section{Fungsi Cemoohan (menghina atau merendahkan, menyindir)}

Disfemisme pada umumnya digunakan sebagai sarana cemoohan. Cemoohan ini meliputi menghina atau merendahkan dan menyindir seseorang dengan ungkapan-ungkapan kasar untuk menyakiti orang yang dirujuk. Menurut KBBI daring, menghina berarti 'merendahkan, memburukkan nama baik orang, serta menyinggung perasaan orang seperti memaki-maki atau menistakan'. Sementara itu, menyindir berarti 'menyatakan sesuatu seperti kritik, celaan, dan ejekan secara tidak langsung'. Berikut contoh data yang ditemukan terkait fungsi cemoohan.

(2) @cherlinwrdly @watwatik Daki kadal nih ko bacot ya. (60/OKV/27/NOV/19)

(3) Iyqah_exol gruop babi (111/OKV/30/NOV/19)

(4) Bernardchrphr @okvitanmd_berdoa dulu aja, mungkin aja $m^{*}$ nyet udah insyaf $(16 / \mathrm{OKV} / 24 / \mathrm{OKT} / 19)$

Pada data (2) ditemukan ekspresi disfemisme berupa ungkapan Daki kadal nih ko bacot ya. Pada data tersebut, terdapat dua ungkapan disfemisme, yaitu frasa daki kadal dan kata bacot. Menurut KBBI daring, daki memiliki arti 'kotoran sisa debu bercampur keringat yang melekat pada tubuh (terutama pada kaki, lengan, leher)'. Sementara itu, kadal adalah salah satu jenis hewan reptil. Kemudian pada ungkapan disfemisme berikutnya, bacot merupakan bentuk akronim dari banyak cocot atau banyak omong. Cocot adalah bahasa Jawa 
berkonotasi kasar dari mulut. Jika dilihat secara keseluruhan data (2), @ cherlinwrdly menghina @watwatik dengan menyamakan dirinya dengan daki dari hewan kadal dan ia yang terlalu banyak bicara dengan menggunakan kata berkonotasi kasar. Penggunaan ungkapan-ungkapan tersebut dinilai kasar karena menyamakan seseorang dengan kotoran yang menempel pada hewan dan menyebutnya banyak bicara dengan pemilihan diksi yang tabu.

Pada data data (3) terdapat ungkapan disfemisme babi. Menurut KBBI daring, babi berarti 'binatang menyusui yang bermoncong panjang, berkulit tebal, dan berbulu kasar'. Menurut KBBI daring, babi pun merupakan umpatan yang sangat kasar. Kata babi digunakan untuk menghina atau merendahkan seseorang. Hal ini dapat dilihat pada unsur gramatikal yang mendahului kata babi, yaitu kata group yang berarti rombongan atau kelompok. Berdasarkan hal tersebut, babi digunakan untuk menghina sebuah kelompok. Cemoohan ini bermakna sangat kasar karena menyamakan sebuah kelompok dengan seekor babi di mana babi memiliki makna seperti yang telah disebutkan sebelumnya. Hal ini tentu saja akan sangat menyakiti perasaan orang-orang yang terdapat dalam kelompok tersebut apabila komentar tersebut dibaca oleh mereka.

Ungkapan disfemisme berikutnya ditemukan pada data (4), yaitu ditemukannya kata $\boldsymbol{m}^{*}$ nyet. $\boldsymbol{M}^{*}$ nyet berasal dari kata dasar monyet. Menurut KBBI daring, monyet berarti 'kera yang bulunya berwarna keabu-abuan dan berekor panjang, tetapi kulit muka, telapak tangan, dan telapak kakinya tidak berbulu'. Dalam data (4), kata monyet digunakan untuk merujuk pada seseorang. Menyamakan seseorang dengan hewan merupakan disfemisme. Penggunaan kata monyet bertujuan untuk menyamakan karakteristik seseorang. Seseorang tersebut dianggap memiliki karakteristik yang sama dengan monyet, yaitu samasama licik. Anggapan ini didasarkan pada pandangan dari sebagian masyarakat yang menganggap monyet sering melakukan kecurangan terhadap sesamanya, khususnya saat mereka memperoleh makanan. Monyet tersebut bersikap licik dalam berebut makanan agar mendapat makanan yang banyak. Hal ini kemudian dikaitkan dengan karakteristik manusia yang licik dan serakah.

Dalam data (4) @bernardchrphr digunakan ungkapan disfemisme untuk menghina seseorang secara tidak langsung dengan menuliskan komentar berdoa dulu aja, mungkin aja $m^{*} n y e t$ udah insyaf. Ungkapan $m^{*} n y e t$ digunakan untuk menyindir seseorang yang tidak disebutkan dalam komentar tersebut. Alih-alih menyebutkan nama seseorang yang dimaksud, @bernardchrphr memilih menggunakan ungkapan $m^{*}$ nyet untuk menyebutkan seseorang yang diharapkan dapat segera insaf dari perilakunya saat ini yang diduga memiliki persamaan sifat licik dengan monyet.

\section{Fungsi menunjukkan kejengkelan}

Penggunaan disfemisme selain untuk menyampaikan cemoohan juga dapat digunakan untuk mengungkapkan kejengkelan. Hal ini biasanya muncul 
karena rasa marah atas sesuatu yang tidak disukai. Berikut paparan terkait fungsi tersebut dalam kolom komentar akun Instagram @officialkvibes.

(5) Drtxxh_ BATALIN AE SEKALIAN NJENG. SEHARUSNYA VOTING

$\begin{array}{llll}\text { MAMA HARUS } & \text { DISELIDIKI SEKALIAN NJENG }\end{array}$

(6) Syifaandini6 MISUH2 JANGAN?! AHHH TAIII (46/OKV/26/NOV/19)

Pada data (5), ditemukan ekspresi disfemisme berupa kata NJENG. NJENG berasal dari kata dasar anjing yang mengalami pelepasan fonem pertama $a_{-}$, kemudian mengalami pemodelan kembali dengan penggantian fonem $-i$ pada suku kata terakhir dengan fonem -e. Anjing memiliki referen hewan menggonggong berkaki empat yang biasanya dihindari karena najis. Dalam data (5), kata anjing digunakan untuk merujuk seseorang. Menyamakan seseorang dengan hewan merupakan tindakan disfemisme.

Pada data (5), secara keseluruhan dapat dilihat bahwa @drtxxh_ mengungkapkan kemarahannya karena sesuatu yang tidak disukainya. Pengungkapan kejengkelan ini ditandai dengan unsur lingual BATALIN $A E$ SEKALIAN dan SEHARUSNYA VOTING MAMA HARUS DISELIDIKI SEKALIAN. Komentar tersebut menjadi penanda pengungkapan kekesalan dengan memberikan kalimat perintah kepada seseorang. NJENG dalam komentar tersebut digunakan oleh @drtxxh__ untuk menegaskan kemarahannya terhadap sesuatu yang disebutnya dengan mama karena kecurangan yang diduga telah dilakukan oleh mama. Penggunaan huruf kapital dalam seluruh komentar yang ditulis juga dapat mempertegas kekesalan yang dialami oleh @drtxxh_. Data (5) dapat diubah menjadi komentar yang bernilai netral jika kata NJENG dilesapkan sebagaimana pada hasil analisis berdasarkan teknik lesap seperti pada analisis (5a) berikut.

(5a) BATALIN AE SEKALIAN. SEHARUSNYA VOTING MAMA HARUS DISELIDIKI SEKALIAN.

Pada data (6) ditemukan ekspresi disfemisme, yaitu penggunaan ungkapan TAIII. Menurut KBBI daring, tai merupakan 'ampas makanan dari dalam perut yang keluar melalui dubur'. Penggunaan istilah dari sebuah hasil aktivitas organ tubuh yang tabu merupakan sebuah disfemisme. Jika data (6) dilihat secara keseluruhan, ungkapan tersebut digunakan untuk mengungkapkan kemarahannya terhadap sesuatu yang terjadi sebelumnya yang tidak disukainya. Pengungkapan kejengkelan tersebut ditandai dengan unsur lingual MISUH2 JANGAN?! Frasa tersebut menegaskan bahwa penulis komentar merasa jengkel hingga ia ingin misuh atau mengumpat. Selain itu, penggunaan huruf kapital untuk setiap fonem pada komentar tersebut dapat menambah kesan kasar dan emosi milik@syifaandini6.

Setelah dilakukan pelesapan ungkapan tai pada data (6), dapat dihasilkan komentar yang bernilai netral, seperti pada hasil analisis (6a) berikut.

(6a) Syifaandini6 MISUH2 JANGAN?! AHHH 


\section{Fungsi menunjukkan ketidaksetujuan}

Selain untuk mengungkapkan cemoohan dan kejengkelan atau kemarahan, disfemisme juga digunakan untuk menunjukkan ketidaksetujuan terhadap sesuatu atau seseorang yang tidak disukai. Ketidaksetujuan terhadap sesuatu ini diungkapkan dengan penggunaan kata-kata yang kasar atau menggunakan ungkapan yang memiliki ungkapan yang berkonotasi kasar. Berikut paparan terkait fungsi disfemisme tersebut.

(7) Ardillafd @queen_lalisa4 mending bubar your ass (27/OKV/26/NOV/19)

(8) Earlyclausitaa @clarizatombeg_ihhhh anjeerrr siapa sudah itu yg ngisi panggungnyaaa $(37 / \mathrm{OKV} / 26 / \mathrm{NOV} / 19)$

Pada data (7) ditemukan ekspresi disfemisme berupa ungkapan your ass. Your ass merupakan istilah dari bahasa Inggris yang berarti pantatmu atau bokongmu. Ungkapan tersebut merupakan istilah bagian tubuh manusia yang dianggap tabu. Ungkapan your ass dalam data (7) digunakan oleh @ardillafd untuk mengungkapkan ketidaksetujuannya terhadap komentar yang dituliskan oleh @queen_lalisa4 sebelumnya. Ketidaksetujuan tersebut diungkapan melalui komentar dengan mengungkapkan mending bubar your ass atau mending bubar pantatmu. Your ass diawali oleh frasa mending bubar. Hal ini bermakna menyangsikan apa yang ditulis pada komentar sebelumnya, yaitu mending bubar. Pengungkapan ketidaksetujuan yang menggunakan istilah tabu tersebut dianggap sebagai bentuk disfemisme.

Ekspresi disfemisme selanjutnya ditemukan dalam data (8), yaitu ungkapan anjeerrr. Anjer merupakan bentuk pemodelan kembali dari kata dasar anjing. Ungkapan anjer atau anjir merupakan ungkapan yang sangat sering ditemukan dalam kolom komentar seperti pada data (8a) dan (8b) berikut.

(8a) Aqiladrrn knp sih anjir. (76/OKV/27/NOV/19)

(8b) Fadilaocti @chairunnnisaaa ha? Di korea gimana? Wkwk anjir lu masih mempertanyakan itu? .... (113/OKV/30/NOV/19)

Ungkapan anjer dalam data (8) digunakan oleh @earlyclausita untuk mengungkapkan ketidaksetujuannya pada sesuatu yang tidak disukainya dengan komentar ihhhh anjeerrr siapa sudah itu yg ngisi panggungnyaaa. @earlyclausita mengungkapkan ketidaksetujuaannya terhadap pengisi panggung yang dimaksud tersebut dengan penambahan ungkapan kasar anjeerrr sehingga komentar tersebut termasuk dalam disfemisme. Penggunaan ihhhh dapat menunjukkan ekspresi tidak suka atau jijik. Penanda lainnya ditunjukkan pada kalimat siapa sudah itu yg ngisi panggungnyaaa. Jika dilihat berdasarkan keseluruhan komentar tersebut, ;'

@earlycalusitaa menunjukkan ketidaksetujuannya atau rasa tidak sukanya dengan pengisi acara di panggung tersebut. 


\section{Fungsi menunjukkan emosi lain (kagum, senang)}

Selain sebagai sarana untuk mencemooh, mengungkapkan kejengkelan, dan menunjukkan ketidaksetujuan, disfemisme juga bisa digunakan untuk menunjukkan emosi selain kemarahan atau kejengkelan. Terdapat beberapa data yang ditemukan dalam kolom komentar akun Instagram @officialkvibes berfungsi untuk menyampaikan emosi lain, yaitu kekaguman dan rasa senang atau kegembiraan akan sesuatu. Fungsi ini merupakan fungsi disfemisme yang sekarang ini sering digunakan oleh masyarakat, khususnya dalam berbagai sosial media. Berikut paparan analisis data terkait fungsi disfemisme tersebut.

(9) Firday.nm Sekalinya ikut award langsung dapet 3 anjir Daniel (56/OKV/26/NOV/19)

Nurnadila.s @fadillaocti ngakak bgt bgst

(109/OKV/29/NOV/19)

Ekspresi disfemisme selanjutnya terdapat pada data (9), yaitu ungkapan anjir. Anjir merupakan bentuk pemodelan kembali dari kata dasar anjing. Anjing dalam sebuah peribahasa anjing ditepuk menjungkit ekor merupakan sebuah simbol atau penggambaran untuk orang hina. Dalam data (9), anjir digunakan untuk mengungkapkan rasa kagum seseorang terhadap sesuatu. Jika dilihat pada komentar keseluruhan, Sekalinya ikut award langsung dapet 3 anjir Daniel, @firday.nm mengungkapkan kekagumannya akan Daniel atas penghargaan yang dia dapatkan. Ungkapan anjir meskipun digunakan untuk mengungkapkan sebuah kekaguman, tetap memiliki makna konotasi yang buruk sehingga termasuk dalam disfemisme. Dalam kehidupan sehari-hari pun, ungkapan ini sering digunakan dalam berbagai penyampaian emosi selain emosi kemarahan. Setelah dilakukan pelesapan pada ungkapan anjir, data (9) dapat diubah menjadi data yang bernilai netral dengan menggantinya menggunakan kata yang bernuansa makna netral sebagaimana dalam hasil analisis (9a) berikut.

(9a) Firday.nm Sekalinya ikut award langsung dapet 3 Daniel

Data disfemisme selanjutnya adalah ungkapan bgst yang terdapat dalam data (10). Bgst berasal dari kata dasar bangsat yang mengalami pelepasan setiap fonem vokal pada setiap suku kata. Menurut KBBI daring, bangsat berarti 'orang yang bertabiat jahat'. Pada data (10), ungkapan bgst digunakan untuk menyampaikan rasa bahagia @nurnadila.s terhadap sesuatu. Hal ini ditandai dengan frasa ngakak bgt yang mendampingi kata bangsat. Ngakak merupakan istilah lain dari tertawa terbahak bahak atau tertawa terpingkal-pingkal. Ungkapan bgst meskipun digunakan untuk menyampaikan rasa bahagia seseorang terhadap sesuatu, ungkapan tersebut tetap memiliki makna konotasi yang buruk sehingga termasuk dalam disfemisme.

Setelah dilakukan pelesapan pada ungkapan bgst, data (10) dapat diubah menjadi data yang bermakna netral seperti pada (10a) berikut.

(10a) Nurnadila.s @fadillaocti ngakak bgt 
Pada data (10), meskipun komentar tersebut tidak menyerang seseorang secara langsung, hal tersebut dapat membuat seseorang yang mendengar atau membaca komentar tersebut merasa risih dan terganggu. Peneliti telah melakukan sedikit wawancara terhadap seseorang dengan menerapkan konteks yang sama dengan ketiga data tersebut. Dalam wawancara kecil tersebut, narasumber mengatakan bahwa ia tetap merasa risih dan terganggu dengan komentar tersebut karena ungkapan tersebut dianggap kasar. Hal ini dapat menjadi bukti bahwa ungkapan tersebut termasuk dalam disfemisme. Hal ini sesuai dengan teori Allan dan Burridge yang menyatakan bahwa disfemisme adalah ungkapan berkonotasi kasar atau bernuansa kasar yang menyerang dan membuat rasa tidak nyaman bagi seseorang yang dituju ataupun pihak ketiga yang mendengar ungkapan tersebut.

Fungsi disfemisme yang ditemukan dalam kolom komentar akun Instagram @officialkvibes sesuai dengan teori Allan dan Burridge. Dalam bukunya yang berjudul Euphemism and Dysphemism: Language Used as Shield and Weapon, Allan dan Burridge menyatakan bahwa disfemisme adalah ungkapan dengan konotasi kasar atau tidak menyenangkan yang digunakan untuk menyerang, menunjukkan ketidaksetujuan, dan merendahkan seseorang. Fungsi disfemisme yang ditemukan dalam penelitian ini sejalan dengan teori yang diungkapkan oleh Allan dan Burridge tersebut. Namun, terdapat satu fungsi disfemisme yang berbeda, yaitu untuk mengungkapkan rasa senang dan kekaguman. Hal ini tentunya menarik dilihat dari sisi definisi disfemisme yang berfungsi untuk melawan maupun mencemooh. Hanya saja, di sini dapat dilihat fungsi yang bertentangan dengan definisi yang dimaksud. Meskipun begitu, hal ini tetap sejalan dengan teori Allan dan Burridge yang menyatakan bahwa sebuah ungkapan dianggap disfemisme tergantung pada suatu konteks, waktu, dan tempat. Sebuah konotasi juga dapat berbeda dari konteks ke konteks lain, dari komunitas satu dengan komunitas lainnya, dan individu satu dengan individu lainnya. Hal ini sejalan dengan wawancara kecil yang telah disebutkan sebelumnya.

Fungsi penggunaan disfemisme tersebut menunjukkan bahwa fungsi penggunaan disfemisme ikut berkembang mengikuti perkembangan zaman dan penggunanya. Disfemisme yang sebelumnya hanya digunakan untuk menunjukkan beberapa emosi, seiring berjalannya waktu, fungsi disfemisme tersebut semakin beragam penggunaannya dalam mewakili ekspresi serta emosi lainnya.

\section{SIMPULAN}

Berdasarkan data-data yang ditemukan dalam kolom komentar akun Instagram @officialkvibes, dapat disimpulkan bahwa fungsi penggunaan disfemisme yang ditemukan dibagi menjadi 4 fungsi. Fungsi-fungsi tersebut terbagi menjadi fungsi cemoohan (menghina, menyindir, merendahkan), fungsi 
menunjukkan kejengkelan, fungsi menunjukkan ketidaksetujuan, dan fungsi menunjukkan emosi lain (kagum, senang). Fungsi cemoohan (menghina atau merendahkan, menyindir) dan fungsi menunjukkan kejengkelan merupakan fungsi penggunaan disfemisme yang paling banyak ditemukan dalam kolom komentar akun Instagram @officialkvibes.

\section{DAFTAR PUSTAKA}

Aini, F. N. (2018). Disfemisme dalam Akun Media Sosial Twitter Majelis Lucu Indonesia. Skripsi. Program Studi Sastra Indonesia Universitas Sebelas Maret. Surakarta.

Allan, K. and Burridge, K. (1991). Euphemism and Dysphemism: Language Used as Shield and Weapon. New York: Oxford University Press.

Allan, K. and Burridge, K. (2006). Forbidden Words: Taboo and the Censoring of Language. New York: Oxford University Press.

Anggraeni, D. W. (2016). Eufemisme dan Disfemisme dalam Talk Show Mata Najwa di Metro TV (Kajian Sosiolinguistik). Skripsi. Surakarta: Universitas Sebelas Maret.

Hermawan, D. H., dkk. (2018). Penggunaan Disfemisme oleh Pembenci (Haters) dalam Instagram pada Akun Artis Ayu Ting Ting. JOM FIKP, 5(1), 1-15.

Heryana, N. (2019). Eufemisme dan Disfemisme pada Media Berita Daring Republika: Perkembangan Kasus Setya Novanto Edisi Januari 2018. Jurnal Visi Ilmu Pendidikan, 11(1), 72-83.

Moleong, L. J. (2005). Metode Penelitian Kualitatif. Bandung: Remaja Rosdakarya.

Ningsih, Ria, A., dan Arianti, R. (2016). Penggunaan Disfemisme oleh Haters (Pembenci) dalam Instagram pada Akun Artis MJ: Kajian Pragmatik. Prosiding Seminar Nasional 31 Juli. Universitas Pasir Pengaraian: 470-477.

Ramadhani, S. (2017). Analisis Bahasa Disfemia dalam Komentar Para Netizen di Situs Online Detik.Com pada Rubrik. Skripsi. Program Studi Pendidikan Bahasa dan Sastra Indonesia Universitas Muhammadiyah Sumatera Utara. Medan.

Sudaryanto. (2015). Metode dan Aneka Teknik Analisis Bahasa. Yogyakarta: Sanata Dharma University Press.

Ulum, D. E. L. dan Kusmanto, H. (2018). Disfemia pada Komentar Akun Instagram Mimi.Peri. Prosiding Semnas KBSP $V$. Universitas Muhammadiyah Surakarta: 232-237. 